\title{
Kualitas Produk dan Kualitas Layanan serta Pengaruhnya Terhadap Keputusan Pembelian produk Filter Paper Whatman di distribusikan oleh PT Laborindo Sarana
}

\author{
Ratih Andalusi ${ }^{1}$; Ahmad Maulana Irfanudin ${ }^{2}$ \\ 1-2Universitas Pamulang, dosen01854@unpam.ac.id, dosen01868@unpam.ac.id
}

\begin{abstract}
Abstrak Penelitian ini bertujuan untuk mengetahui Kualitas Produk, kualitas Layanan dan pengaruhnya terhadap Keputusan Pembelian Produk Filter Paper Whatman yang didistribusikan oleh PT. Laborindo Sarana. Mettode yáng digunakan adalàh kausal deskriiptif mlalui pendkatan kuantitatif. Riset dekriptif di gunakan untuk memberikan gambaran karakteristik responden yang dalam hal ini merupakan pelanggan tetap Laborindo Sarana yang membeli produk filter paper, type causal mengukur kekuatan hubungan dua variabel atau lebih, menunjukkan variabel bebas dan variabel terikat serta hubungannya. Pengambilan sampel dengan metode sensus atau sampel jenuh, dengan jumlah responden keseluruhan 112 orang. Teknik Analisis yang dilakukan yaitu kualitas data meliputi validitas dan reliabilitas, dan asumsi klasik yaitu uji normalitas dan auto korelasi, serta uji regresi linier, koefisien determinasi, dan uji hipotesis dengan menggunakan aplikasi pengolah data SPSS 20. Hasil penelitiaan menunjukkan terdapat pengaruh positif dan signifikan antara kualitas produkterhadap Keputusan pembelian dengan persamaaan regresi linier berganda $\mathrm{Y}=8,729+0,258_{x_{1}}+0,294_{x_{2}}$. Nilai $R$-Square snilai 0,393 yang mengindikasikan kualitas produk dan Layanan teerhadap Keputusan Pembelian memberikan kontribusi sebesar 39.3\%, Uji simultan $\mathrm{F}$ kualitas produk dan Layanan sebesar 23,335> 2,690 dengan nilai sig 0,000<0,1 yang artinya terdapạt pengạruh yạng positif dan sigifikan antạra kualitas produk dan layanan terhadạp keputusan pembelian produk filter paper whatman.
\end{abstract}

Kata kunci : Kualitas Produk; Layanan; Keputusan Pembelian; Filter Paper.

Abstract. This study aims to determine the effect of Product Quality and Service Quality on the Whatman Paper Filter Product Purchase Decision which is distributed by PT. Laborindo Sarana. The research method used is descriptive causal with a quantitative approach. Descriptive research is used to provide an overview of market characteristics, in this case the respondents who are Laborindo Sarana customers who buy filter paper products, type causal measures the strength of the relationship between two or more variables, showing the independent variable and the dependent variable and their relationship. Sampling by census method or saturated samples, with a total of 112 respondents. The analysis technique used is validity test, reliability test, and classical assumptions, namely normality test and auto correlation test, as well as linear regression test, coefficient of determination, and hypothesis testing using the SPSS 20 data processing application. product quality and service quality on purchasing decisions with the regression equation $Y=8,729+0,258_{x 1}+0,294_{x 2}$. The value of the coefficient of determination is 0.393 which indicates the quality of the product towards purchasing decisions contributes $39.3 \%$, the rest is explained by other variables outside of this study. The results of the partial $F$ test are 23,335>2,690, and with a sig.value of $0,000<0.1$, meaning that means there is a positive and significant effect, product quality and service quality on purchasing decisions for filter paper Whatman products.

Keyword : Product Quality; Service; Purchase Decision; Filter Paper 


\section{A. PENDAHULUAN}

Globallisasi membạwa dampak yang sangat besar bagi perkembangan riset di bidang life science di Indonesia, membuat peluang yang meluas serta mmbangun pasar yang melebar, hal ini diikuti berkembangnya perusahaan distribusi di bidang analytic di Indonesia, PT. Laborindo Sarana adalah salah satunyá.

Semakin meningkatnya permintaan pasar maka akan semakin banyak peluang untuk membuka perusahan yang bergerak dibidang pemasaran alat dan bahan laboratorium, sehingga menimbulkan persaingan antar sesama perusahaan, maka dari itu PT. Laborindo Sarana harus mengembangkan strategi agar dapat menjaga para pelanggannya dengan cara meningkatkan kualitas pelayanan dan produknya agar sesuai kebutuhan daripada pasar riset.

PT Laborindo sarana, Perusahaan distributor dengan spesialisasi alat penunjang Laboratorium yang telah eksis sejak tahun 1992, Laborindo menyediakan kebutuhankebutuhan riset laboratorium, seperti laboratorium riset, laboratorium Quality Control dan sebagian kebutuhan laboratorium medis. Saat ini Laborindo Sarana dipercaya untuk memegang lebih dari 10 keagenan produk asing seperti : Whatman, Sigma Aldrich, SCIEX, Hygiena, Peak Scientific, MPW, Human, Brooks, Perkin Elmer, dan Zew Lab. Produk yang dijual oleh PT Laborindo sarana di impor langsung dari negara asal produk.,berbekal izin Kemendagri nomoor 75/M-DAG/PER/10/2014 mengenai perizinan mendatangkan impor B2 (Barang Berbahaya) seperti misalnya merkuri, besi oksida (seperti misalnya Red Iron Oxide) ataupun besi hidroksida, salah satunya adalah IP Bahan Berbahaya (B2) atau Importir Produsen Bahan Berbahaya (IP-B2)

Filter paper adalah salah satu bahan habis pakai yang berbentuk tipis seperti kertas yang biasanya digunakan untuk menyaring larutan yang akan di analisa di laboratorium. Semakin berkembangnya teknologi dan pasar khususnya dibidang analisis dan riset laboratorium sehingga bermunculan berbagai jenis filter paper sehingga menimbulkan persaingan yang ketat, yang menuntut perusahaan untuk dapat mencipta kebijakan strategis untuk memenangkan pasar risett.

Merek WHATMAN ini sendiri merupakan merek yang sudah cukup dikenal dikalangan pengguna alat laboratorium riset. Dikarenakan kualitas produk yang diberikan terbukti handal. Posisi merek WHATMAN ini sendiri dibandingkan dengan merek lain adalah sebagai market leader. Pangsa pasar dari merek Whatman ini di indonesia terbagi menjadi 3 bidang yaitu:

1. Riset, dimana pangsa pasar ini menguasai $30 \%$ dari total. Pengguna di bidang riset ini antara lain adalah Universitas, contohnya: Universitas Indonesia.

2. Applied Market, dimana pangsa pasar ini menguasai $55 \%$ dari total. Pengguna bidang applied market ini adalah Laboratorium Uji, contohnya: Laboratorium Forensik Kepolisian dan Balai Pengujian Obat dan Makanan.

Bio Proses, pangsa pasar ini menguasai 15\% dari total. Bio Proses ini hampir sama dengan riset, karena berfungsi untuk melakukan riset juga tetapi lebih spesifik pada bidang vaksin dan obat - obatan.

Tetapi walaupun kualitas produk WHATMAN yang dijual cukup baik, tidak menjamin bahwa tidak ada permasalahan yang timbul terkait dengan kualitas pelayanan perusahaan. Permasalahan yang sering dikeluhkan oleh pelanggan secara umum antara lain:

1. Respon yang lama.

Respon yang lama disini yang dimaksud adalah respon baik dari sales, admin maupun after sales yang tidak segera merespon permintaan dari pelanggan.

2. Keterlambatan Distribusi

Permasalahan yang sering dikeluhkan disini adalah lamanya waktu yang dibutuhkan hingga barang/ jasa tersebut sampai/dikerjakan di tempat pelanggan.

3. Harga yang mahal

Banyak pelanggan yang mengeluhkan harga untuk barang/ jasa untuk merek WHATMAN ini sangat mahal.

4. Kualitas produk 
Produk filter paper yang banyak dimiliki competitor menjadi ancaman untuk penjualan filter paper whatman.

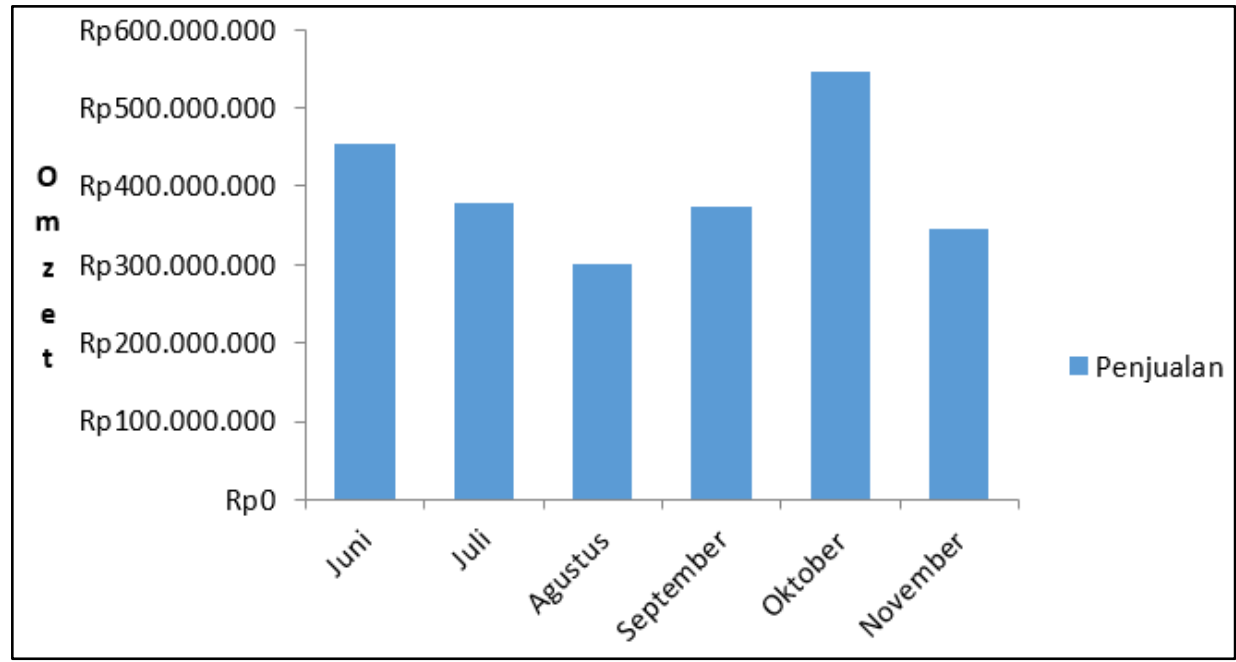

Gambar 1

Data Penjualan Produk Whatman distribusi Laborindo Sarana

Volume penjualan filter paper di distributor resmi pada Laborindo Sarana, PT. 6 bulan belakangan sifatnya fluktuatif naik-turun, dapat dilihat berdasar Gambar 1.1, volume penjualan menguat pada bulan Juni dan Oktober 2020 dan mengalami penurunan pada bulan Juli, Agustus dan November 2020. Hal ini besar kemungkinan terjadi dikarenakan masuknya kompetitor sejenis dari merek yang berbeda, seperti brand Millipore dengan promosi besar-besarannya dan beberapa brand filter paper baru. Jelas mempengaruhi merek kertas saring WHATMAN sehingga terhambatnya peningkatan penjualan serta sulitnya eksis mempertahankan pangsa, yang jika berlanjutt akan berdampak kepada besarnya volum peenjualan.

Berdasarkan uraian dan latar belakang permasalahan yang ada dan disebutkan diatas, peneliti mengambil tema untuk penelitian ini dengan tajuk "Kualitas Produk dan Kualitas Layanan serta Pengaruhnya Terhadap Keputusan Pembelian Filter Paper Whatman Didistribusikan oleh PT Laborindo Sarana".

\section{Rumusan Masalah}

Berdasarkan pada uraian di latar belakang, maka dapat dirumuskan masalah pada penelitian ini yakni (1) bagaimana pengaruh kualitas produk terhadap keputusan pembelian produk filter paper Whatman yang didistribusikan PT Laborindo Sarana?; (2) bagaimana pengaruh kualitas layanan terhadap keputusan pembelian produk filter paper Whatman yang didistribusikan PT Laborindo Sarana?; serta (3) bagaimana pngaruh kualitas produk dan kualitas layanan secara bersamaan terrhadap keputusan pembelian produk filter paper Whatman yang didistribusikan PT Laborindo Sarana?

\section{Tujuan Penelitian}

a. Menganalisis dan Mengetahui bagaimana pengáruh Kuálitas produk Filter Paper Whatman terhadap keputusan pembelian

b. Menganalisis dan Mengetahui bagaimana pengáruh Kuálitas Layanan terhadap keputusan pembelian

c. Menganalisis dan Mengetahui pengaruh kuálitas produk dán kualitas layanan Filter Paper Whatman terhadap Keputusan Pembelian customer PT Laborindo Sarana. 


\section{B. KAJIAN LITERATUR}

Dalam usaha meningkatkan income perusahaan, pemasaran memegang peranan yang vital, untuk itu perlu diketahui taktik dalam melakukan pemasaran, Menurut Freddy (2012:49) yaitu (1) Diferensi, yang berkaitan dengan acara membangun strategi pemasaran dalam berbagai aspek di perusahaan. Kegiatan membangun strategi pemasaran inilah yang membedakan diferensi yang dilakukan oleh perusahaan lain, dan (2) Bauran pemasaran, yang berkaitan dengan kegiatan-kegiatan mengenai produk, harga, promosi dan tempat.

Kotler (2006) menyebutkan "Marketing mix is the set of marketing tools that the firm to uses to pursue its marketing objectives in the target market" yang diartikan kurang lebihny Bauran pemasaran adalah seperangkat alat pemasaran yang digunakan perusahaan untuk mengejar tujuan pemasarannya di pasar sasaran.

Ketika membahas strategi untuk memasarkan barang, tenaga pemasar biasanya memperhatikan empat unsur strategi dasar yaitu: produk, harga, tempat (atau distribusi) dan promosi (komunikasi). Tetapi sifat jasa, yang melibatkan berbagai aspek keterlibatan pelanggan dalam produksi dan pentingnya faktor waktu, membutuhkan unsur startegis lainnya.

Lovelock dan Wright (2002) melengkapi pengembbangan marketing mix menjadi integrated services management dengan menggunakan pendekatan 8P terpadu yaitu "product elements, place, cyberspace, and time promotion and education, price and other user outlays, process, productivity and quality, people and physical evidence".

\section{Product Quality}

Karakteristik suatu produk atau jasa menentukan kualitas produk atu jasa itu sendiri, yang akan memengaruhi tingkat kpuasan kustomer dalam penggunaannya. Tjiptono (2009), mendefinisikan dimensi kuàlitas próduk meliputi:

a. Kinerja (performance)

Yaitu karakteristik operasi pokok dari produk inti (core product) yang dibeli, misalnya Kualitas jaringan telepon yang jernih, kecepatan akses data (internet), kemudahan dan kenyamanan aktivitas selular dan sebagainya.

b. Keistimewaan tambahan (features)

Yaitu karakteristik sekunder atau pelengkap, misalnya layanan prioritas pengguna pascabayar.

c. Kehandalan (reliability)

Yaitu kemungkinan kecil akan mengalami kegagalan fungsional, misalnya akses jaringan yang terbatas di daerah terpencil.

d. Ksesuaian déngan spésifikasi (conformance to specifications)

Seberapa sesuai antara krakteristik deesain dan operasional dalam hal pemenuhan standar yang ditettapkan. Sebagai contoh, penentuan jumlah kuota data internet atau kesesuaian tarif dan jaringan telepon.

e. Daya tahan (durability)

Berkaitan dengan berapa lama produk tersebut dapat terus digunakan.

f. Estetika (asthethic)

Yaitu daya tarik produk terhadap panca indera. Misalnya bentuk pengemasan produk yang menarik, model dan desain yang artistic, dan

g. Perceived quality (kesan kualitas).

\section{Service Quality}

Service Quality atau Kualitas Layanan oleh Tjiptonó (2013) mengatakan "Kualitas jasa atau kualitas pelayanan yang mendefinisikan sebagai kondisi dinamis yang berhubungan 
dengan produk, jasa, sumber daya manusia, proses dan lingkungan yang memenuhi atau melebihi harapan."

Assauri (2003) mengatakan jika kostumer melihat kualitas pelayanan segera setelah mereka menerima layanan atas produk atau jasa yang akan dibeli dari suatu perusahaan. Keputusan pembelian dibentuk salah satunya oleh kualitas pelayanan yang diterima kostumer, selain kualitas produk atau jasa, faktor internal maupiun eksternal, pribadi dan sosial.

\section{Pengukuran Kualitas Pelayanan}

Tjiptono (2013) mencanangkan suatu alat pengukur kualitas pelayanan yang disebut SERVQUAL (Service Quality). SERVQUAL menggunakan scale untuk mengukur persepsi kustomer atas kualitas pelayanan melalui item pertanyaan pertanyaan, yang mewakili dimensinya masing-masing, yakni (1) Reliability, adalah kehandalan memberikan pelayanan dengan segera, akurat dan memuaskan, (2) Responsiveness, adalah pelayanan cepat tanggap karyawan dalam melayani kostumer, (3) Assurance, berkaitan dengan kesopanan, kepercayaan serta kemampuan karyawan dalam pelayanan, (4) Empathy, dalam hal komunikasi dan hubungan antar karyawan dengan kostumer dan kebutuhannya, serta (5) Tangibles, yang berkaitan dengan fasilitas fisik, perlengkapan, sarana-prasarana.

\section{Keputusan Pembelian}

Keputusan pembelian yakni proses kustomer mempertimbangkan brand, produsen, tenagaa penjual, kuàntitas, waktu, jenis produk, dan carà peembayaran untuk memenuhi kebutuhàn sebelum akhirnya memutuskan melakukan pembelian. Kotler dan Armstrong (2012) mngatakan "Consumer buyer behavior is the buying behavior of final consumerindividuals and households who buy goods and services for personal consumption". Sedangkan Schiffman dan Kanuk (2007) menyatakan "A decision is a selection on action from two or more alternative choices", yang berarti dalam melakukan pembelian barang atau jasa, kustomer memiliki lebih dari satu pilihan sebelum akhirnya memutuskannya.

Kotler dan Keller (2012) mejabarkan dimensi képutusan pembelian sebagai berikut: (a) Pemilihan Produk, (b) Pilihan Brand (Merek), (c) Pemilihan Penyalur, (d) Jumlah Pembelian, (e) Penentuan Waktu kunjungan, dan (f) Metode Pembayaran

Melihat paparan diatas didukung dari teori-teori para pakar terkait, maka hipotesis yang dapat disimpulkan sebagai berikut:

$\mathrm{H}_{01}$ : Kualitas Produk Diduga tidak terdapat pengaruh yang positif dan signifikan terhadap Keputusan Pembelian Filter Paper Whatman Didistribusikan oleh PT Laborindo Sarana

$\mathrm{Ha}_{1}$ : Kualitas Produk Diduga terdapat pengaruh yang positif dan signifikan terhadap Keputusan Pembelian Filter Paper Whatman Didistribusikan oleh PT Laborindo Sarana

$\mathrm{H}_{\mathrm{o} 2}$ : Kualitas Layanan Diduga tidak terdapat pengaruh yang positif dan signifikan terhadap Keputusan Pembelian Filter Paper Whatman Didistribusikan oleh PT Laborindo Sarana

$\mathrm{Ha}_{2}$ : Kualitas Layanan Diduga terdapat pengaruh yang positif dan signifikan terhadap Keputusan Pembelian Filter Paper Whatman Didistribusikan oleh PT Laborindo Sarana

$\mathrm{H}_{\mathrm{03}}$ : Kualitas Produk dan Kualitas Layanan Diduga tidak terdapat pengaruh yang positif dan signifikan terhadap Keputusan Pembelian Filter Paper Whatman Didistribusikan oleh PT Laborindo Sarana

$\mathrm{Ha}_{3}$ : Kualitas Produk dan Kualitas Layanan Diduga terdapat pengaruh yang positif dan signifikan terhadap Keputusan Pembelian Filter Paper Whatman Didistribusikan oleh PT Laborindo Sarana 


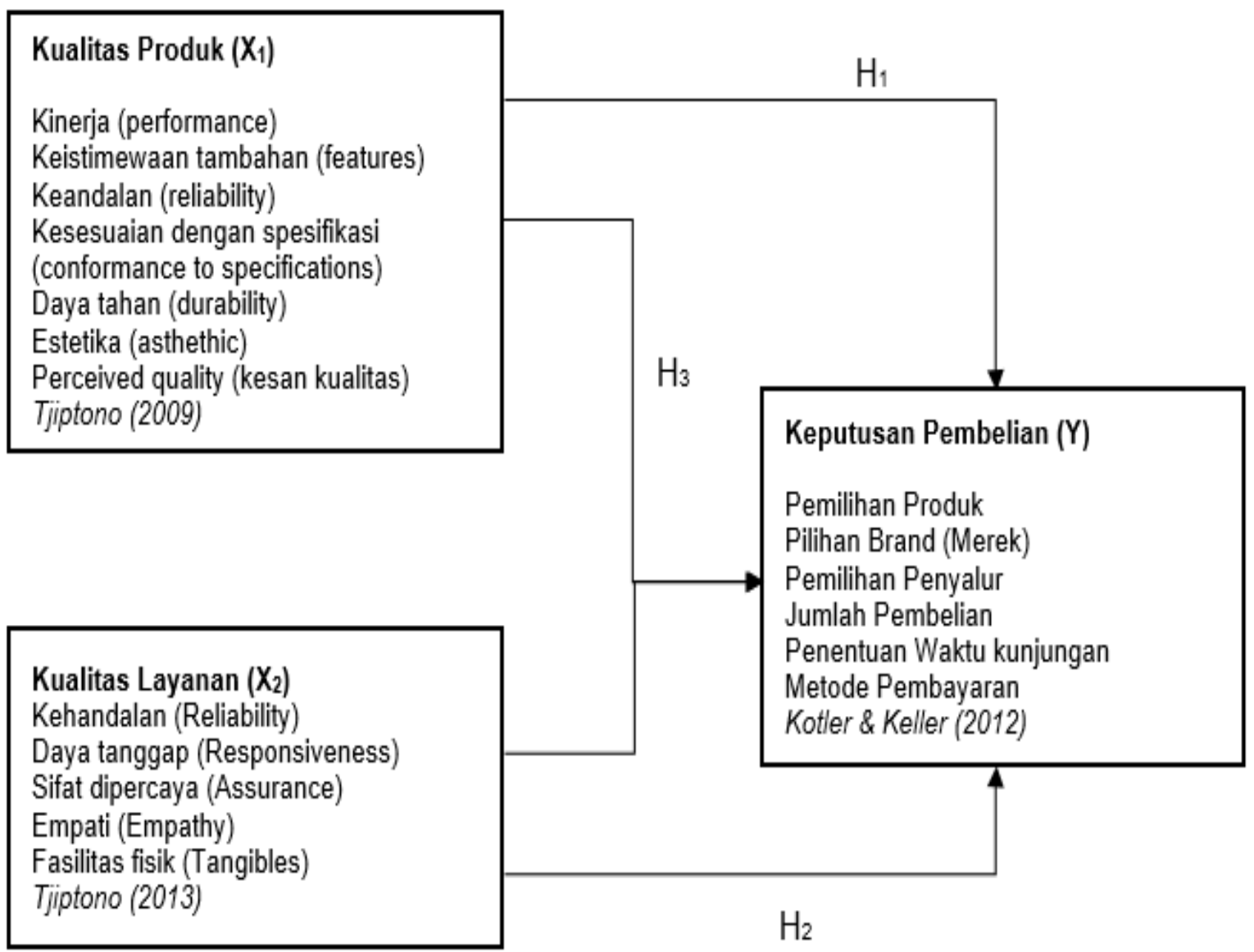

\section{Gambar 2. Kerangka Berpikir}

\section{B. METODOLOGI PENELITIAN}

Objek Penelitian ini adalah Laborindo Sarana, PT. Divisi khusus barang habis pakai. berlokasi di JIn.AlteriRaya 8A PondokIndah JakartaSelatan. Dimana subyek teliti adalah pengguna sekaligus kustomer filter paper whatman yang melakukan pemesanan ke Laborindo Sarana, PT. Untuk mengetahui keputusan pembelian yang dipengaruhi oleh kwalitas produk dan layanan.

Metode penelitian yang digunakan yakni tipe kausal dengan pendekatan kuantitatif. metode dekriptif memberikan gaambaran trhadap kaarakteristik responden, sedangkan tipe causal penelitian adalah meng ukur kekuatan huubungan antar dua variabel atau lebih, arah hubungan antara variabel bebas dengan variabel terikat, yang dalam hal ini adalah kualitas produkk filter paper whatman, kualitas layanan serta keputusan pembelian. Populasi dalam penelitian ini adalah pengguna produk filter paper berjumlah 112 responden dimana populasi merupakan pengguna produk filter paper yang dijual oleh PT Laborindo Sarana. Penelitian ini menggunakan semua populasi sebagai sample penelitian, yang seringkali disebut sebagai metod sensus. 


\section{HASIL DAN PEMBAHASAN}

\section{Analisa Data}

Proses analisa data dapat di peroleh gam baran hasil penelitian, pengolahan data responden dari instrumentasi penelitian berupa kuesioner dengan jumlah yang telah ditetapkan sebelumnya. Pengumpulan data di pastikan sesuai dengan kaidah dan persyaratan yang terpenuhi untuk dianalisa, serta di interpretasikan agar dapat menjadi solusi atas permasalahan yang ada.

\section{a. Uji Validitas}

Tabel 1. Validitas Kualitas Produk ( $\left.X_{1}\right)$

\begin{tabular}{|c|c|c|c|}
\hline \multicolumn{4}{|c|}{ Kualitas Produk (X) } \\
\hline Kuesioner & r-hitung & r-tabel & Keputusan \\
\hline Pernyataan 1 & 0,684 & 0.186 & Valid \\
\hline Pernyataan 2 & 0,700 & 0.186 & Valid \\
\hline Pernyataan 3 & 0,682 & 0.186 & Valid \\
\hline Pernyataan 4 & 0,753 & 0.186 & Valid \\
\hline Pernyataan 5 & 0,779 & 0.186 & Valid \\
\hline Pernyataan 6 & 0,651 & 0.186 & Valid \\
\hline
\end{tabular}

Tabel 2. Validitas Kualitas Layanan $\left(X_{2}\right)$

\begin{tabular}{|c|c|c|c|}
\hline \multicolumn{4}{|c|}{ Kualitas Layanan (X2) } \\
\hline Kuesioner & r-hitung & r-tabel & Keputusan \\
\hline Pernyataan 1 & 0,745 & 0.186 & Valid \\
\hline Pernyataan 2 & 0,620 & 0.186 & Valid \\
\hline Pernyataan 3 & 0,701 & 0.186 & Valid \\
\hline Pernyataan 4 & 0,805 & 0.186 & Valid \\
\hline Pernyataan 5 & 0,304 & 0.186 & Valid \\
\hline Pernyataan 6 & 0,855 & 0.186 & Valid \\
\hline Pernyataan 7 & 0,814 & 0.186 & Valid \\
\hline
\end{tabular}

Tabel 3. Validitas Keputusan Pembelian (Y)

\begin{tabular}{|c|c|c|c|c|}
\hline \multicolumn{4}{|c|}{ Keputusan Pembelian (Y) } \\
\cline { 2 - 5 } & Kuesioner & r-hitung & r-tabel & Keputusan \\
\cline { 2 - 5 } & Pernyataan 1 & 0,748 & 0.186 & Valid \\
\cline { 2 - 5 } & Pernyataan 2 & 0,746 & 0.186 & Valid \\
\cline { 2 - 5 } Jurnal Pemas & Pernyataan 3 & 0,683 & 0.186 & Valid \\
\cline { 2 - 5 } & Pernyataan 4 & 0,692 & 0.186 & Valid \\
\cline { 2 - 5 } & Pernyataan 5 & 0,714 & 0.186 & Valid \\
\cline { 2 - 5 } & Pernyataan 6 & 0,626 & 0.186 & Valid \\
\cline { 2 - 5 } & Pernyataan 7 & 0,587 & 0.186 & Valid \\
\cline { 2 - 5 }
\end{tabular}


Melihat pada data kedua tabel hasil uji validitas masing-masing variable di atas, variabel Kualitas Produk $\left(X_{1}\right)$, Kualitas Layanan $\left(X_{2}\right)$ dan kinerja karyawan $(Y)$ memperoleh nilai $r_{\text {hitung }}>r_{\text {tabel }}(0.186)$, maka dari itu semua pernyaataan kuesioner dinyatakan valid dan karena nya kuesioner yang digunakan dikatakan layak sebagai instrumentasi penelitian.

\section{b. Uji Reliabilitas}

Uji yang menentukan kehandalan suatu kuesioner dalam mengukur konsistensi jawaban responden setiap saat. Dibawahini merupakan hasil dari pengujian Realibilitas dngan mnggunakan aplikasi SPSS20.

Tabel 4. Hasil Uji Reliable

\begin{tabular}{|c|c|c|c|}
\hline Variabel & $\begin{array}{c}\text { Cronbach's } \\
\text { Alpha }\end{array}$ & N of Items & $\begin{array}{c}\text { Kategori Interval } \\
\text { Reliabilitas }\end{array}$ \\
\hline Kualitas Produk (X1) & $\mathbf{0 , 7 9 0}$ & 6 & Reliabel \\
\hline Kualitas Layanan (X2) & $\mathbf{0 , 8 2 8}$ & 7 & Reliabel \\
\hline Keputusan Pembelian (Y) & $\mathbf{0 , 8 1 0}$ & 7 & Reliabel \\
\hline
\end{tabular}

Dapat kita perhatikan hasil pengujian diatas bahwa setiap variabel memiliki nilai alpha Cronbach melebihi batas aman reliabel $(0,6)$, jadi dapat dikatakan bahwa setiap point pernyataan kuisionner bersifat reliabel dan dapat digunakan waktu kewaktu.

2. Uji Asumsi Klasik

a. Uji Normalitas Data

Hasil uji Normalitas salah satunya data bisa dilihat melalui grafik P-Plot dibawah ini. Jika data distribute normal, penggambaran garis data akan mengikuti garis normal diagonal (Ghozali, 2010).

\section{Hasil Uji Normalitas Data}

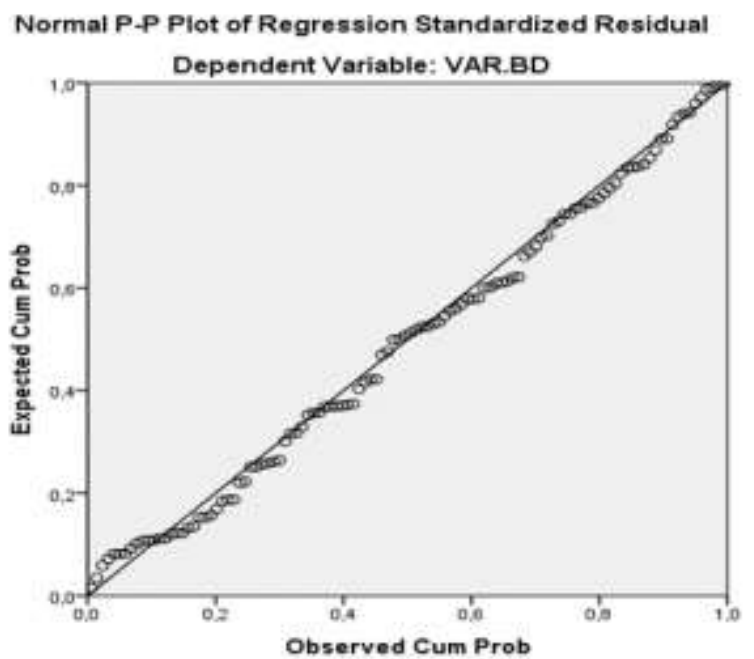


Hasil Pengujian memnuhi asumsi normalitas dapat dilihat titik-titik data tersebar disekitar wilayah garis diagonal. 


\section{Autokorelasi}

Tabel 5. Pengujian Autokorelasi

\begin{tabular}{|l|c|r|r|r|c|}
\hline \multicolumn{5}{|c|}{ Model Summary } \\
\hline Model & R & R Square & Adjusted R Square & $\begin{array}{c}\text { Std. Error of the } \\
\text { Estimate }\end{array}$ & $\begin{array}{c}\text { Durbin- } \\
\text { Watson }\end{array}$ \\
\hline 1 & $.673^{\mathrm{a}}$ & .442 & .427 & & 5.070 \\
\hline
\end{tabular}

Sumber: Pengolahan Data dengan SPSS20

Durbin Watson score diatas menunjukkan angka 1.740 , hal ini berarti pengujian model regreesi tidak terdapat Autokorelasi, karena berada di intrval data antara 1.550-2.460

\section{Uji Regresi Linier Berganda}

Berikut dibawah ini merupakan persamaan regresi linier berganda, yang daripadanya dapat dilihat pengaruh variabel bebas yang adalah kualitas produk $\left(X_{1}\right)$, kualitas layanan $\left(X_{2}\right)$ terhadap variabel terikat nya yaitu keputusan pembelian $(\mathrm{Y})$

Tabel 6. Hasil Uji Regresi Linier Sederhana

\begin{tabular}{|l|l|r|r|r|}
\hline \multicolumn{2}{|c|}{} & \multicolumn{3}{|c|}{ Coefficients $^{\mathbf{a}}$} \\
\hline \multirow{2}{*}{ Model } & \multicolumn{2}{c|}{$\begin{array}{c}\text { Unstandardized } \\
\text { Coefficients }\end{array}$} & $\begin{array}{c}\text { Standardized } \\
\text { Coefficients }\end{array}$ \\
\cline { 2 - 5 } & \multicolumn{2}{|c|}{ B } & Std. Error & \multicolumn{1}{c|}{ Beta } \\
\hline \multirow{3}{*}{1} & (Constant) & 8.729 & 2.465 & .500 \\
\cline { 2 - 5 } & VAR.KP & .258 & .072 & .500 \\
\cline { 2 - 5 } & VAR.KP & .294 & .073 & \\
\hline
\end{tabular}

a. Dependent Variable: VAR.BuyingDecision

Sumber: Pengolahan Data dengan SPSS20

Dari hasil regresi pada tabel diatas yang didapat maka dibuat persamaan regresi sebagai berikut:

$$
Y=8,729+0,285 X_{1}+0,294 X_{2}+e
$$

\section{Uji Koefisien Determinasi $\mathbf{R}^{2}$}

Pengujian ini berutjuan untuk menjelaskan seberapa besar pengaruh yang ditimbulkan oleh variabel bebas terhadap variabel terikatnya, pada tabel dibawah ini dapat dilihat nilai berdsasarkan kolom $\mathrm{R}$ Square

Tabel 7. Hasil $\mathbf{R}^{2}$

Model Summaryb

\begin{tabular}{|l|r|r|r|r|}
\hline Model & $\mathrm{R}$ & $\mathrm{R}$ Square & \multicolumn{1}{|c|}{$\begin{array}{l}\text { Adjusted R } \\
\text { Square }\end{array}$} & $\begin{array}{l}\text { Std. Error of the } \\
\text { Estimate }\end{array}$ \\
\hline 1 &, $627^{\mathrm{a}}$ &, 393 &, 376 & 2,145 \\
\hline
\end{tabular}

a. Predictors: (Constant), VAR.KP, VAR.KL

b. Dependent Variable: VAR.BD 


\section{Sumber: Pengolahan Data dengan SPSS20}

Dari tabel diatas, dapat dijelaskan sebagaiberikut :

a) Coefficient $R$ sebesar 0.393. Artinya korelasi kualitas produk Keputusan Pembelian sebesar 0.393 , yang berarti terdpat hubungan positif dengan nilai 0.393 antar variable kual.produk, layanan trhadap keputusann pembaelian.

b) Coefficient Adjusted $\mathrm{R}$ Square bernilai 0.376, mengindikasikan bahwa kual.produk dan layanan terhadàp Keputusan Pembelian berkontriibusi sebesar $37.6 \%, 62,4 \%$ sisanya djelaskan olehh variable lain diluar penelitian.

\section{Uji Hipotesis}

\section{a. Uji Simultan (F)}

\section{Tabel 8. Hasil Uji F}

ANOVA

\begin{tabular}{|l|l|r|r|r|r|r|}
\hline \multicolumn{2}{|l|}{ Model } & Sum of Squares & df & Mean Square & F & Sig. \\
\hline \multirow{4}{*}{1} & Regression & 322.089 & 2 & 107.363 & 23.335 & $.000^{\mathrm{b}}$ \\
\cline { 2 - 7 } & Residual & 496.911 & 111 & 4.601 & & \\
\cline { 2 - 7 } & Total & 819.000 & 113 & & & \\
\hline
\end{tabular}

a. Dependent Variable: VAR.BD

b. Predictors: (Constant), VAR.KP, VAR.KL

Sumber: Pengolahan Data dengan SPSS20

Diatas dapat diperhatikan tabel Anova memperoleh hasil hitung Nilai $F$. Nilai df $1=\mathrm{k}-1$, dimana $\mathrm{k}$ merupakan jumlah variabel yang diteliti, sehingga df 1 = 4-1 adalah 3, dan df2 $=\mathrm{n}-\mathrm{k}$, dimana $\mathrm{n}$ merupakan jumlah sampel dalam penelitian ini yaitu 113. Sehingga df2 $=113-2$ adalah 111, maka penentuan nilai $F$ tabel sebesar 2,69.

Perhitungan menunjukkan nilai $F$ hitung 23.335 , hal ini berarti $F$ hitung lebih besar daripada $F$ tabel, serta hasil nilai signifikansi 0,000 lebih besar daripada nilai sig $5 \%(0,05)$ yang artinya secara bersamaan, variable kual.produk dan kual.layanan mempengaruhi variable terikat yakni keputusan pembelian

\section{E. KESIMPULAN}

Jadi penulis memberikan kesimpulan hasil anilisis serta pembahasan yang telah dijelaskan sebelumnya, adalah sebagai berikut:

1. Kualitas Produk filter paper Whatman yang di distribusikan oleh Laborindo Sarana,PT berdasarkan 6 (enam) indikator yang diinterpretasikan dengan 6 (enam) butir pernyataan, diberikan kepada 112 orang responden, memiliki skor rata-rata 3.85 , masuk dalam jajar nilai 3.41 - 4.20 dengan kategori Baik. Terlihat dari jawaban responden pada pernyataan "Produk kertas saring whatman memiliki varian yang luas sesuai dengan kebutuhan laboratorium".

2. Kualitas Layanan filter paper Whatman yang di distribusikan oleh Laborindo Sarana,PT berdasarkan 5 (lima) indikator yang diinterpretasikan dengan 7 (tujuh) butir pernyataan, diberikan kepada 112 orang responden, memiliki skor rata-rata 3,7; masuk dalam jajar nilai 3.41 - 4.20 dengan kategori Baik. Terlihat dari jawaban responden pada pernyataan "Produk kertas saring merk whatman yang ditawarkan sesuai dengan kebutuhan laboratorium".

3. Keputusan Pembelian produk filter paper Whatman dilihat dari 7 (tujuh) indikator yang diinterpretasikan lewat 7 (tujuh) bulir pernyataan dalam kuesioner, lalu dibeirkan 
kepada 112 orang responden, meiliki skor rata-rata 4,04; masuk dalam jajar nilai 4.20 - 5.00 yang artinya dalam kategori Sangàt Baik. Di dominasi oleh jawaban respondnen atas pernyataan "Pelanggan memilih kertas saring berdasarkan brand" dan "Pelanggan akan mencari informasi prihal kertas saring whatman yang akan dibeli sesuai dengan kebutuhan".

4. Seluruh variabel bebas berpengaruh positif dan signifikan terhadap variabel terikat yakni KeputusanPembelian filter paper Whatman yang didistribusikan PT Laborindo Sarana karena nilai signifikan yakni 0,001, < 0,05 dan nilai $F$ hitung (23.335) lebiih besar dariipada nilai $F$ tabel (2.69), bntuk pngaruhnya positif berdasarkan pada nilai koef regresi X1 dan X2 yang berrnilai posiitif, yaitu 0.258 dan 0,294.

\section{DAFTAR PUSTAKA}

Ahmad Maulana Irfanudin, et all. (2020). Pengaruh Kualitas Produk Dan Promosi Terhadap Keputusan Pembelian Produk Pristine 8+ Pada PT Super Wahana Tehno. Jurnal SeMaRak, 103-119.

Anwar Prabu Mangkunegara, 2006, Evaluasi Kinerja SDM, Refika Aditama, Bandung.

Ariawan, Iwan, 1998. Besar dan Metode Sampel Pada Penelitian Kesehatan. Jurusan Biosatistik dan Kependudukan Fakultas Kesehatan Masyarakat Universitas Indonesia.

Arikunto, S, 1983, Metode Research, Rajawali Pers, Jakarta.

Azhari, 2001. Hubungan Antara Faktor Internal dan Faktor Eksternal Dengan Prestasi Belajar Siswa Di SPK Depkes Lubuk Linggau Tahun 2001. Tesis Program Pasca Sarjana IImu Kesehatan Masyarakat, Fakutas Kesehatan Masyarakat Universitas Indonesia, Depok.

Azwar, Saifuddin, 1998. Tes Prestasi Fungsi dan Pengembangan Pengukutan Prestasi balajar. Yogyakarta : Pustaka Pelajar Offset.

Chandra, Ardhian, 2016. Pengaruh Kualitas Pelayanan dan Bauran Pemasaran terhadap Loyalitas Pelanggan melalui Kepuasan Pelanggan dan Brand Loyality pada PT.Laborindo Sarana. Tesis Program Pasca Sarjana IImu Manajemen, Fakultas Ekonomi, Universitas Pancasila. Depok.

Deswarto, 2001. Hubungan Antara Motivasi Belajar Dan hasil Ujian Seleksi Masuk Dengan Prestasi Belajar Mahasiswa Di Akademi Keperawatan Departemen Keshatan Palembang Propinsi Sumatera Selatan Tahun 2001. Skripsi Program Sarjana Fakutas Kesehatan Masyarakat Universitas Indonesia, Depok.

Djamarah, Syaiful Bakri, 1994. Prestasi Belajar dan Kompetensi Guru. Usaha Nasional Surabaya

Endranto, Agung Jaya, 2001. Hubungan Antara Nilai Ujian Masuk FKM UI Dengan Indeks Prestasi Pada mahasiswa SKM Jalur B Angkatan tahun 1998 dan 1999/2000. Skripsi Program Sarjana Fakutas Kesehatan Masyarakat Universitas Indonesia, Depok.

Ghozali, 2005, Analisis Multivariant dengan Program SPSS, UNDIP, Semarang.

Gulo, W, 2005. Strategi Belajar Mengajar. PT Gramedia Widiasarana Indonesia, Jakarta.

Hague, Paul, 1995. Merancang Kuesioner.Pustaka Binaman Pressindo, Jakarta.

Hastono, Sutanto Priyo, 2001. Analisis Data. Jakarta : Fakultas Kesehatan Masyarakat Universitas Indonesia.

Hastono, Sutanto Priyo, 2007. Analisis Data Kesehatan. Jakarta : Fakultas Kesehatan Masyarakat Universitas Indonesia. 
Hatta, Gemala R, 2008. Pedoman Manajemen Informasi Kesehatan di Sarana Pelayanan Kesehatan (Revisi). Jakarta : UI Press

Hidayat, Eka Putra Syarif,2003. Hubungan Nilai Ujian Masuk Dan Motivasi Dengan Prestasi Belajar Mahasiswa Jurusan Teknik Radiodiagnostik Politeknik Kesehatan Jakarta II Departemen Keshatan Tahun 2003 . Tesis Program Pasca Sarjana IImu Kesehatan Masyarakat, Fakutas Kesehatan Masyarakat Universitas Indonesia, Depok.

Kementerian Kesehatan, 2010. Kurikulum Pendidikan Diploma III Politeknik Kesehatan Kemenkes Jakarta II.

Kementerian Kesehatan, 2011. Petunjuk Teknis Seleksi Penerimaan Mahasiswa Baru Pendidikan Tenaga Kesehatan, Kementrian Kesehatan Republik Indonesia. Jakarta.

Kementerian Kesehatan, 2013. Profil Politeknik Kesehatan Kemenkes Jakarta II.

Kementerian Kesehatan, 2015. Profil Politeknik Kesehatan Kemenkes Jakarta II.

Kotler, Philip \& Gary Amstrong. (2015). Priciples of Marketing. 15e Global Edition. Pearson

Kotler, Philip and Kevin Lane Keller. (2012). Marketing Management, Edisi 14, New Jersey:

Kotler, Philip and Kevin Lane Keller. (2016). Marketing Management, 15th Edition, Pearson Education, Inc.

Lesmana, R. (2019). Pengaruh Kualitas Produk Dan Kualitas Pelayanan Terhadap Kepuasan Konsumen Pt. Radekatama Piranti Nusa. Jurnal Pemasaran Kompetitif, 2(2), 115-129.

Lesmana, R., \& Ayu, S. D. (2019). Pengaruh Kualitas Produk Dan Citra Merek Terhadap Keputusan Pembelian Kosmetik Wardah PT Paragon Tehnology And Innovation. Jurnal Pemasaran Kompetitif, 2(3), 59-72.

Lesmana, R., Widodo, A. S., \& Sunardi, N. (2020). The Formation of Customer Loyalty From Brand Awareness and Perceived Quality through Brand Equity of Xiaomi Smartphone Users in South Tangerang. Jurnal Pemasaran Kompetitif, 4(1), 1-12.

Marehwati, Agung, 2002. Hubungan Antara Hasil Ujian Masuk Sipensimaru Dengan Prestasi Belajar Mahasiswa Akademi Kesehatan Gigi Depkes Propinsi Jambi Tahun Ajaran 2000/2001. Tesis Program Pasca Sarjana Ilmu Kesehatan Masyarakat, Fakutas Kesehatan Masyarakat Universitas Indonesia, Depok.

Prentice-Hall Published

Slameto, 2003. Belajar dan Faktor-Faktor yang Mempengaruhinya.. PT Rineka Cipta, Jakarta.

Sukadji, Soetarlinah, 2000. Sikap dan Kebiasaan Belajar, Indeks Prestasi Kumulatif dan Lama Studi Mahasiswa Psikologi Universitas Indonesia. Jurnal Penelitian Makara UI Volume 4 Seri C Edisi Sosial Ekonomi dan Budaya, Universitas Indonesia, Depok.

Sunardi, N., \& Lesmana, R. (2020). Konsep Icepower (Wiramadu) sebagai Solusi Wirausaha menuju Desa Sejahtra Mandiri (DMS) pada Masa Pandemi Covid19. JIMF (Jurnal Ilmiah Manajemen Forkamma), 4(1).

Sunardi, N., Lesmana, R., Kartono, K., \& Rudy, R. (2020). Peran Manajemen Keuangan dan Digital Marketing dalam Upaya Peningkatan Omset Penjualan bagi Umkm Pasar Modern Intermoda Bsd City Kota Tangerang Selatan di Tengah Pandemi Covid19. Jurnal Abdi Masyarakat Humanis, 2(1).

Suryabrata, Sumadi,1997. Psikologi Pendidikan,Manajemen PT Raja Grafindo Persada Jakarta,Universitas Gadjah Mada, Yogyakarta 